The Battelle Institute undertakes research for the sole benefit of each client and hands over all results, including patents, the work being carried out on a completely confidential basis. At Geneva, research is being done in physics, chemistry and metallurgy by the staff of eighty-five people. Serious consideration is given to new fields of research as industry demands them, so that, like the Columbus and Frankfurt Laboratories, the Geneva Laboratory is a dynamic rather than a static organization. Each project receives the full attention of the Institute's entire research facilities in the United States and Europe. The volume of research already achieved makes it evident that the Battelle Institute can be as helpful in Europe as it has been in the country of its origin.

\section{THE COLOMBO PLAN : TECHNICAL CO-OPERATION SCHEME}

$\mathrm{U}$

NDER the Technical Co-operation Scheme of the Colombo Plan, which completed its fourth year in June 1954 (The Colombo Plan. Technical Co-operation Scheme. Report for 1953-54 by the Council for Technical Co-operation in South and South-East Asia. Colombo, July 1954. London: H.M.S.O., 1954. 1s. net), training was arranged in 1953 for 608 persons as against 538 in 1952, and 1,653 places have now been provided in all, mostly for graduates with a background of experience which enables them to benefit from their specialist training abroad in various fields of economic development. By June 30, 1954, the largest group (268) went abroad for training in food and agriculture; of the others, training in government administration claimed 266, engineering 192, medicine and health 168, education 135, transport and communications 132, industry and trade 131, and power and fuel 123 . The United Kingdom provided facilities for 638 trainees, including 211 from India, 195 from Ceylon and 157 from Pakistan. Of Australia's 487 trainees, 116 came from India, 91 from Pakistan, 80 from Indonesia and 79 from Coylon. Canada has taken 210 trainees (93 from Pakistan and 92 from India), New Zealand, 170 (45 from Ceylon, 39 from Malaya, 35 from India and 32 from Pakistan), while India has taken 137 trainees, including 67 from Ceylon and 23 from Pakistan. The figures indicate that while Pakistan and Indonesia are concentrating on training in administration, India and Ceylon are concentrating on training facilities in food and agriculture.

The demand for experts has been heaviest in the field of medicine and health. The 58 experts provided in 1953 (compared with 90 in 1952 and 45 in 1951) brought the total provided to 263 as against 502 applied for ; and of these, 69 are in medicine and health, 36 in transport and communication, 33 in engineering, 33 in food, agriculture and forestry, 25 in education and 23 in industry and trade. Of the 115 experts provided by the United Kingdom, both India and Ceylon took fifty. Of 45 supplied by Canada, 22 went to Ceylon, 10 to Pakistan and 9 to Malaya. Of New Zealand's 30 experts, 12 went to Pakistan. Although 239 requests were outstanding, offers are still awaited against only 133.

Requests for equipment for use by experts or for training and research institutions since the beginning of the Scheme have totalled $£ 1.5$ million, against which equipment to the value of $£ 1$ million has been supplied or offered. Requests totalling $£ 714,500$ have been received from Pakistan, $\$ 591,700$ from India and $£ 171,000$ from Ceylon. Equipment supplied or agreed in principle by the United Kingdom includes $£ 14,000$ worth for the Technical High School, Karachi, and $£ 155,000$ for nine new technical high-schools in Pakistan, £50,000 worth for the Mercantile Marine Academy, Pakistan, and $£ 82,000$ for the Pakistan Department of Scientific and Industrial Research, $£ 139,000$ for the Textile Training Centre, Lyallpur, $£ 70,000$ for the National Metallurgical Laboratory, Jamshedpur, $£ 24,000$ for the Central Testing and Standards Laboratories at Karachi and Dacca, $£ 37,500$ for the Central Water Power, Irrigation and Navigation Research Station, Poona, £12,380 for the Bengal Engineering College, Calcutta, $£ 18,300$ for the Research Laboratory of the Forest and Education Branch of the Ceylon Forest Department, $£ 25,000$ for the Central Science Teaching Centre, Bandung, and Teacher Training Centres at Djogjakarta and Surabaya.

\section{BIOLOGY AND A GENERAL UNIVERSITY EDUCATION}

A CONFERENCE on "Biology and a General University Education", organized by the Institute of Biology, was held at the University College of North Staffordshire, Keele, on December 20-21. Most of those attending were paying their first visit to Keele, and it was clear from what was said at dinner-table and in common rooms that they generally liked what they saw and heard of the College. There was appreciation, too, of the inclusion in the general education for which North Staffordshire stands, not only of biology but also of those traditional academic graces which are so conspicuously lacking in some of the universities born of the industrial revolution.

In the first session, under the chairmanship of Prof. S. Zuckerman, three speakers described biology courses for arts students that are already in existence. Prof. A. R. Gemmell dealt with biology as one alternative for the compulsory natural science subject. for students of the humanities or social sciences at Keele. He tries to give his students an insight intothe scientist's approach and some knowledge of the nature of laboratory work, to relate the science to the student's own background of knowledge, and to stimulate him to think. The centre of the course is man, and there are fifty-two lectures, on mammalian physiology and anatomy, parasitism and disease, genetics and agriculture. There is a three-hour practical class each week, including dissection of the rabbit and some work with Drosophila. Dr. J. Hutchens (Chicago) then described biology as a part of the general education course at his university. Here physical science is studied as well, and before biology, and the students include those who will later specialize in sciences as well as the humanities. The emphasis in the biology course is on the physiology of man; but the laboratory course begins with microscopy-pond water, blood cells and so on-a practice of which Dr. Hutchens does not approve. There are differences of approach in different parts of the course, some stressing details and others general principles. For the most part, the teaching in general education is done by a separate staff from 